\title{
Physiological and sanitary quality of seeds of Dimorphandra gardneriana Tul. treated with essential oils
}

Sueli da Sllva Santos de Moura*1, Alinne Menezes Soares², Marina Matias Ursulino², Robério de Oliveira ${ }^{3}$, Luciana Cordeiro Nascimento ${ }^{3}$, Edna Ursulino Alves ${ }^{3}$

'Federal Institute of Alagoas, Alagoas, Brazil,

2 Federal Institute of Maranhão, Viana, Brazil

${ }^{3}$ Federal University of Paraíba, Areia, Brazil,

*Corresponding author, e-mail: suelidasilvasantos@yahoo.com.br

\begin{abstract}
Dimorphandra gardneriana, popularly known as fava d'anta, is a medicinal species whose fruits and seeds are used in the manufacture of medicines. The objective of this study was to evaluate the efficiency of clove (Syzygium aromaticum (L.) Merr. \& L.M. Perry) and copaíba (Copaifera sp.) essential oils in antifungal treatment of seeds of $D$. gardneriana and their influence on physiological quality of the seeds. Two experiments were carried out in a completely randomized design using seeds treated with different concentrations of copaiba and clove oils $(0.5,1.0,1.5$, and $2.0 \mathrm{~mL}$ ) and two controls-seeds were treated with distilled water or fungicide. The variables analyzed were: incidence of fungi in seeds in the first experiment and seed germination and vigor (first germination, length and dry mass of root and shoot of the seedlings) in the second one. The incidence of fungi of the genera Aspergillus sp., Penicillium sp., and Rhizopus sp. in the seeds was elevated. The copaiba oil at the concentrations used did not satisfactorily reduce the incidence of fungi in the seeds of $D$. gardneriana, while the treatment of the seeds with clove oil at concentrations of 2.0 and $0.5 \mathrm{~mL}$ reduced the incidence of Penicillium sp. and Rhizopus sp., respectively. Seed germination and vigor increased at concentrations of $2 \mathrm{~mL}$ of clove oil and $1.25 \mathrm{~mL}$ of copaiba oil.
\end{abstract}

Keywords: Germination, medical plant, seed treatments

\section{Introduction}

The species Dimorphandra gardneriana

Tul., is a native tree of Brazil from the Fabaceae family (Montano et al., 2007). It is small in size, with thin and tortuous stem, bipinnate leaves, composite, and sessile flowers arranged in spikes (Landim; Costa, 2012).

The fruits of $D$. gardneriana are used for extraction of the flavonoid rutine, a promising substance in the production of drugs because it slows aging and combats degenerative diseases (Gonçalves et al., 2010; Ladim; Costa, 2012). Its seeds are used to extract galactomannan, a highly viscous substance commonly known as gum used in the food and pharmaceutical industry (Torio et al., 2006). The tree is used in the production of wood, coal, and cellulose, and the species is utilized in reforestation and recovery of degraded areas, all of which has increased the demand for D. gardneriana seeds (Leite et al., 2012).

Seed is considered to be the most efficient way of disseminating pathogens and introduction of a disease into new areas, which results in reduced production of crops due to damage such as pre- and post-emergence seedling death, root rot, shoot infection, and reduced physiological quality of seeds. In addition, the seed is a source of inoculum that can promote progressive increase of a given disease in the 
field, thereby reducing the commercial value of the crop (Flávio et al., 2014). Microorganisms present in seeds reduce its viability, causing deterioration and consequently compromising sanitary and physiological quality of the seeds (Martins Netto, Faiad, 1995). Nevertheless, there is a great lack of information about the presence of microorganisms in seeds and their effects on seed germination and development of forest plant species (Mesquita et al., 2002).

Seed treatment is a valuable and effective measure because of its simple execution and the relatively low cost (Machado, 2000). However, the high cost of chemicals and the risk of contamination of people and the environment questions the use of such treatments. The high demand for organic products and the search for a less polluting agriculture encouraged the conduct of studies on the use of alternative products for seed treatment (Flávio et al., 2014). In this context, the implementation of essential oils, balsams, and plant extracts may be an alternative to the use of chemical agents in the handling of phytopathogens, aiming to control fungi and other microorganisms present in seeds, especially those that cause post-emergence damages of the seedlings (David et al., 2006).

Some studies have demonstrated the efficiency of these products in the preservation of the seed physiological quality. For example, germination of Mimosa caesalpiniifolia Benth. seeds was increased when they were treated with essential oil of fennel, Pimpinella anisum L. (Leite et al., 2012), whereas germination of Pseudobombax marginatum (A.St.-Hil., Juss \& Cambess.) A. Robyns seeds was not affected by the treatment with oil extracted from copaiba, Copaifera sp. (Mondego et al., 2014). Flávio et al. (2014) reported that treatment of sorghum seeds, Sorghum bicolor (L.) Moench, with araticum essential oil (Annona crassiflora Mart.) did not compromise their viability and vigor.

Due to the economic importance of D. gardneriana, the raw material of this species is collected by extraction and there is no management program established to prevent the extinction of its natural populations (Gonçalves et al., 2010). Therefore, it is necessary to study its seeds to obtain information that will help its conservation and propagation. The objective of this study was to evaluate the efficiency of clove essential oils (Syzygium aromaticum (L.) Merr. \& L.M. Perry) and copaíba (Copaifera sp.) in sanitary treatments of seeds and their influence on physiological quality.

\section{Material and methods}

The experiments were conducted at the Phytopathology and Seed Analysis Laboratories of the Department of Plant and Environmental Sciences, Center of Agricultural Sciences, Federal University of Paraíba, Areia-PB. The seeds of $D$. gardneriana used in this study were collected in Crato (Ceará, Brazill), which is located at $07^{\circ} 14^{\prime} 03^{\prime \prime} \mathrm{S}$ and $39^{\circ} 24^{\prime} 34^{\prime \prime} \mathrm{W}$ and altitude of $426 \mathrm{~m}$. The seeds were scarified in the region opposite to the yarn before being submitted to treatments with different concentrations of copaiba and clove essential oils.

The treatments used consisted of the control (T1) (seeds without treatment), treatment with the fungicide Captan® (T2) at the rate recommended by the manufacturer, and treatments with $0.5,1.0,1.5$, and $2.0 \mathrm{~mL}$ of the essential oils of Copaiba $(T 3, T 4, T 5, T 6)$ and cloves (T7, T8, T9, T10) diluted in Tween and $100 \mathrm{~mL}$ of deionized and sterilized distilled water (ADE).

Before the application of each treatments, the seeds were disinfected with $3 \%$ sodium hypochlorite for 3 min and then immersed in the solutions with essential oils for 5 min. Treated seeds were placed in petri dishes containing two sheets of filter paper moistened with distilled deionized and sterilized water. A total of 25 replicates of 10 seeds each were prepared per treatment. The petri dishes were incubated in a temperature-controlled room at $22 \pm 2{ }^{\circ} \mathrm{C}$ and a $12 \mathrm{~h}$ photoperiod for 7 days.

After this period, the fungi that developed on the seeds were identified based on their morphological characteristics that were visualized under a stereoscopic microscope and compared with the specialized literature (Marthur and Kongsdal, 2003). The incidence of pathogens on seeds was expressed as a percentage and calculated according to the methodology proposed by Silva et al. (2011).

To evaluate the treatment influence on 
the seed physiological quality and germination and vigor tests (first count, length and dry mass of the roots and shoot) were performed as described below. Germination test was conducted with four replicates of 25 seeds for each treatment, which were distributed on two sheets of germitest paper and covered with a third paper moistened with distilled water in the amount equivalent to 2.5 times its dry mass. The seeds were placed in a germinator of the biochemical oxygen demand (BOD) type set to a constant temperature of $25^{\circ} \mathrm{C}$ and photoperiod of $12 \mathrm{~h}$. Germinated seeds were counted from 7 to 21 days after the test installation, and the evaluations were performed according to the criteria for seed analysis (Brazil, 2009). Normal seedlings were those with perfect root and shoot morphology. Percentage of abnormal seedlings was evaluated at the end of the germination test by computing the percentage of seedlings with some essential structures missing or deteriorated. First germination count was performed together with the germination test by computing the percentage of normal seedlings obtained on the seventh day after the test installation. Length and dry mass of the seedlings was determined after the last germination test. For each treatment, the length of normal seedlings and their root and shoot parts were measured using a ruler graduated in centimeters; the results were expressed in $\mathrm{cm}^{-1}$. The same seedlings were then placed in Kraft paper bags and dried in an oven at $65^{\circ} \mathrm{C}$ until constant weight ( $\left.48 \mathrm{~h}\right)$. Dried samples were weighed on an analytical balance with an accuracy of $0.001 \mathrm{~g}$ and the results were expressed in gram per seedlings.

The experimental design was completely randomized, with treatments distributed in a factorial scheme $2 \times 4+2$ (oils, concentrations, fungicide, and absolute control), totaling in 10 treatments, with 25 replicates of 10 seeds per treatment to evaluate the pathology and four replicates of 25 seeds per treatment to evaluate seed physiological quality. The data were submitted to the analysis of variance, and significance of the results was assessed by the $\mathrm{F}$ test and regression analysis by testing the linear and quadratic models using the statistical program Saeg 9.1.

\section{Results and discussion}

As indicated on Figure 1, the most prominent genera of fungi associated with the seeds were Aspergillus, Penicillium, and Rhizopus. The incidence of A. niger (Figure 1A) was reduced noticeably in treatments with $2 \mathrm{~mL}$ of clove oil, while in treatments with copaiba oil, their incidence was higher at all the evaluated concentrations than in the control (Te), in which fungi were present with an incidence of $60 \%$. In contrast, in the treatment with the fungicide, whose active compound is dicarboximide (captan), there was a $95 \%$ control of this fungus.

Copaiba oil consists mainly of caryophyllene and kaurenoic acid, which have anti-inflammatory, antifungal, and analgesic properties (Pieri et al., 2009). However, the antifungal property of these compounds was not sufficient to inhibit the emergence of A. niger. In the seeds of Amburana cearensis (Allemão) A.C. Smith, Oliveira et al. (2011) similarly verified a high incidence of $A$. niger and found that seed origin affected the incidence of this fungus, with the seeds collected in Petrolina-PE having the best sanitary quality.

Aspergillus niger, a cosmopolitan saprophytic fungus, causes problems during the storage of plant organs and seeds because it accelerates the process of degradation and deterioration, especially if the stored plant parts have high water content (Oliveira et al., 2011). It is also worth mentioning that storage fungi of the genus Aspergillus, besides causing damages to seeds and seedlings, produce mycotoxins that can cause food poisoning (Pinto, 2001).

The incidence of Aspergillus sp. (Figure 1B) of $64 \%$ was detected in the seeds that were not submitted to any treatment (Te) and of only $10 \%$ in those treated with the fungicide $\left(T_{2}\right)$. In treatments with copaiba oil, a higher incidence (58\%) of seeds infected with Aspergillus sp. was $=$ Captan ${ }^{\circledR}$ fungicide. Aspergillus niger (A), Aspergillus sp.1 (B), Penicillium sp. (C), Rhizopus sp. (D).

The incidence of the fungus Penicillium sp. increased linearly with increasing clove oil concentrations, but in treatments with copaiba oil, the data did not fit polynomial regression models as the average incidence of $41 \%$ was 
found in untreated seeds, $22 \%$ in those treated with this oil, and $3 \%$ in those treated with fungicide (Figure 1C). In treatments of seeds with clove oil, the concentration of $0.5 \mathrm{~mL}$ clove oil inhibited the incidence of Rhizopus in $89 \%$ of seeds, while the treatments with the highest and
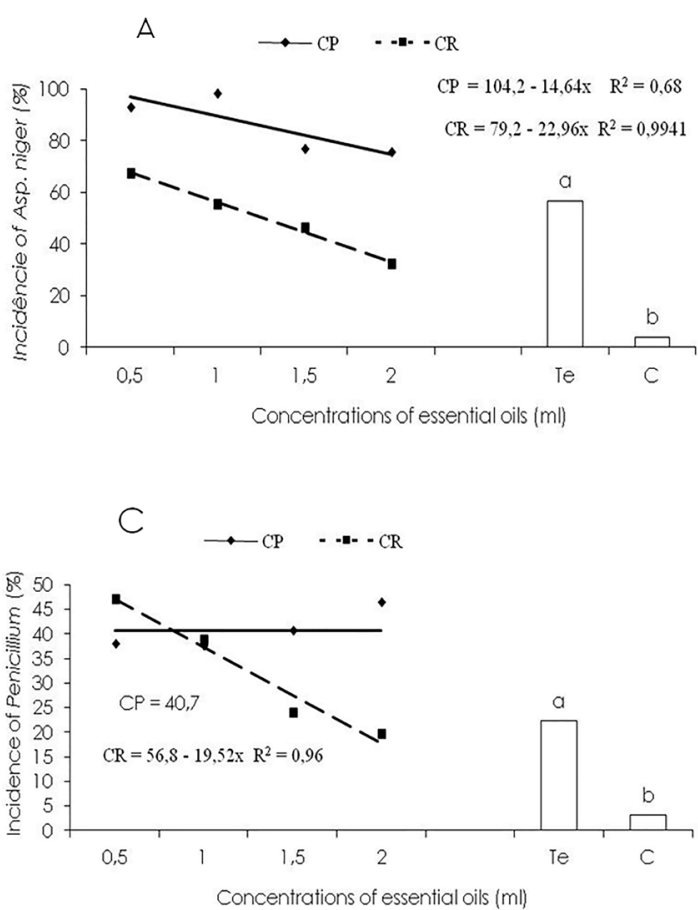

lowest concentrations of copaiba oil resulted in the lowest reduction of fungal infection, $40 \%$ and $38 \%$, respectively. The percentage of fungicide-treated seeds infected by Penicillium sp. increased by only 6\% (Figure 1D).
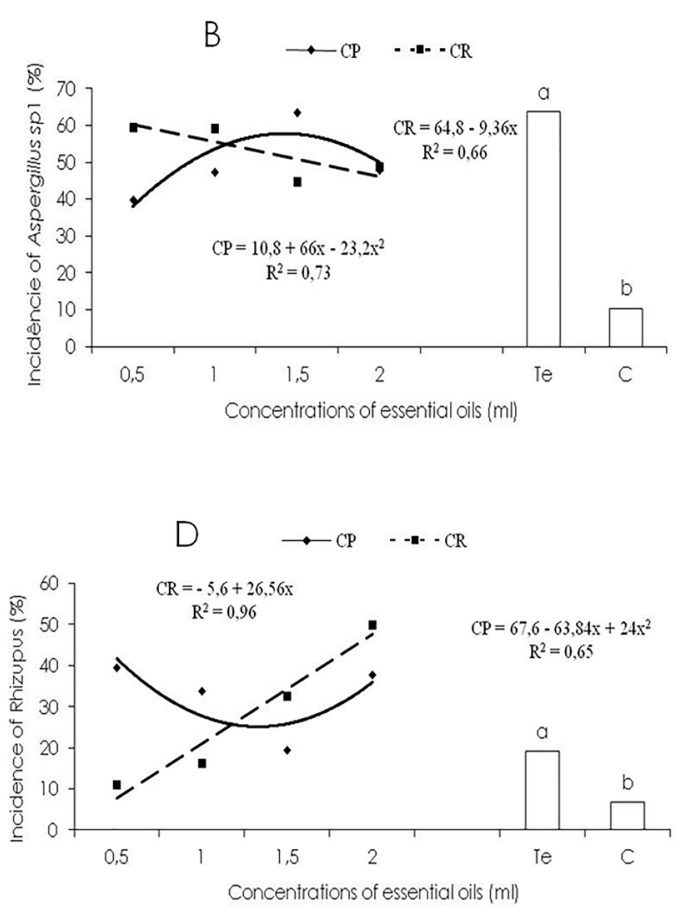

Figure 1. Incidence of fungi on Dimorphandra gardneriana seeds after treatments with clove (CR) and copaíba (CP) oils at concentrations of $0.5,1.0,1.5$, and $2.0 \mathrm{~mL}$. (Te) $=$ control, $(\mathrm{CA})=$ Captan ${ }^{\circledR}$ fungicide. Aspergillus niger (A), Aspergillus sp.1 (B), Penicillium sp. (C), Rhizopus sp. (D).

In general, the chemical treatment was the most efficient in the control of the fungal incidence on seeds of D. gardneriana, although its action varied with species. In the seeds of Amburana cearensis from the city of Catolé do Rocha-PB, Oliveira et al. (2011) reported an incidence of $100 \%$ of $A$. niger in a chemical treatment using the same fungicide. Silva et al. (2011) reported a lower incidence of the genus Aspergillus in seeds of cassia tree (Senna siamea (Lam.) H.S. Irwin \& Barneby), Dalbergia nigra (Vell.) Allemão ex Benth., and pink trumpet tree (Tabebuia heptaphylla (Vell.) Toledo) seeds, with averages of $0.2,1.8$, and $2.4 \%$, respectively, when submitted to chemical treatment.

The seeds of D. gardneriana were highly contaminated with fungi Aspergillus niger, Aspergillus sp., and Penicillium sp., which are storage fungi that can cause seed damage and compromise their quality, resulting in germination process deterioration and death (Lazarotto et al., 2010). Therefore, the control of these fungi, which are responsible for reduction of seed viability and longevity, must be carried out to prevent damages caused by high seed infection rate (Silva et al., 2011).

The highest germination rate of the seeds of $D$. gardneriana was observed in treatments with $2 \mathrm{~mL}$ of clove oil, while the treatments with copaiba oil exhibited a quadratic effect, as the percentage of germination was higher in seeds treated with $1.25 \mathrm{~mL}$ of copaiba oil. Concentrations below and above $1.25 \mathrm{~mL}$ of copaiba oil affected the germination by allowing a higher fungal incidence, which contributed to the deterioration of the seedlings (Figure 2A).

The mean final germination rate and the first count did not differ statistically between the control seeds, those treated with oil, and the ones that were chemically treated (germination 
rate was 48, 59, and 28\%, respectively) (Figure $2 \mathrm{~A}$ and $\mathrm{B}$ ). The highest percentage of abnormal seedlings was observed when the seeds were treated with $0.5 \mathrm{~mL}$ of clove and copaiba essential oils (Figure $2 \mathrm{C}$ ), which may be related to the higher incidence of fungi, mainly $A$. niger as can be verified in Figure $1 \mathrm{~A}$.

Possibly the fungi present in the seeds were located in the surface layers of the seeds where they were removed by the disinfection step with $3 \%$ sodium hypochlorite, resulting in their reduced incidence during the germination process and ultimately no difference between the chemical treatment and the control (Te). The highest first germination count of $D$. gardneriana seeds was obtained in treatments with $1.25 \mathrm{~mL}$ of clove oil in relation to the seeds treated with copaiba oil, whose data were not adjusted to regression models, with mean values of $31 \%$ (Figure 2B).
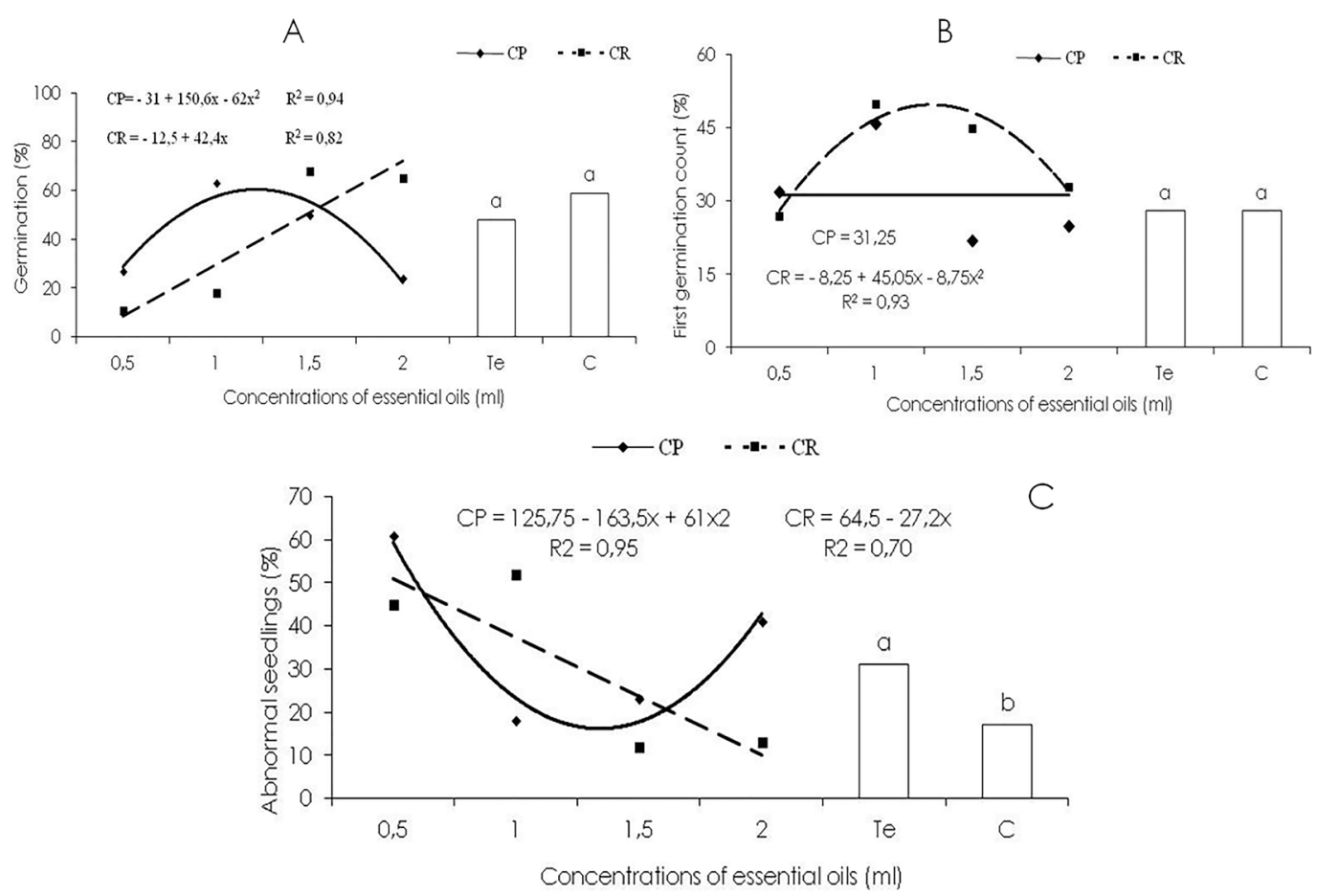

Figure 2. Percentage of germination (A), first germination count (B), and percentage of abnormal seedlings (C) of Dimorphandra gardneriana after treatments with clove (CR) and copaíba (CP) oils at 0.5, 1.0, 1.5, and 2.0 mL concentrations. $(\mathrm{Te})=$ control, $(\mathrm{CA})=$ Captan ${ }^{\circledR}$ fungicide .

These results are similar to those obtained by Leite et al. (2012) with sabia seeds (Mimosa caesalpiniifolia) and by Lazarotto et al. (2013) with cedro seeds (Cedrela fissilis Vell.), who reported no statistical difference between the chemical treatment and the control. The use of the fungicide Captan ${ }^{\circledR}$ (Medeiros et al., 2012) increased the germination of the seeds of cumaru de cheiro (Amburana cearensis) (Oliveira et al., 2011) and flamboyant-mirim (Caesalpinia pulcherrima (L.) Sw.) in relation to the control. In contrast, Pinto et al. (2014) found that the concentrations of rosemary extract (Lippia microphylla Cham.) were harmful to seed germination, causing high seedling mortality.

In their studies conducted with mulungu seeds (Erythrina velutina Willd.), Oliveira et al. (2009) verified that both thermotherapy and chemical treatment affected seed vigor as evidenced by the first count, whereas Leite et al. (2012) found that the application of plant extracts on sabia seeds (Mimosa caesalpiniifolia) contributed to the highest germination rate in the first count.

The treatment of seeds with $2 \mathrm{~mL}$ of clove oil resulted in a lower percentage of abnormal seedlings, while the lowest percentages of abnormal seedlings were obtained in treatments with concentrations between 1 and $1.5 \mathrm{~mL}$ of copaiba oil. Thus, these concentrations were not detrimental to the seed quality and they inhibited the development of fungi during the germination 
process (Figure 2C). The presence of pathogens in seeds can cause irreversible damage both in the germination and post-germination processes, causing losses through deterioration, abnormalities, and lesions in seedlings (Lazarotto et al., 2010).

The positive influence of the alternative products on the control of pathogens present in the seeds and the determination of the ideal quantity that will not impair their physiological quality is important because both seeds and pathogens can react differently to products and concentrations used. In a research conducted by Lazarotto et al. (2013) to verify the efficiency of the treatment on cedro seeds (Cedrela fissilis) with a biological product based on Trichoderma spp. and Captan® fungicide, the number of abnormal seedlings was reduced in both the biological treatment and in its combination with the fungicide.

A differentiated effect of the two oils was observed on the root and shoot length (Figure 3). There was a significant linear increase in the growth of D. gardneriana seedlings when the seeds were treated with clove oil, whereas the seedlings length after treatments with copaiba oil did not conform to the polynomial regression models, having an average length of $4 \mathrm{~cm}$ (Figure 3A). The concentrations of clove oil of less than $1.5 \mathrm{~mL}$ negatively affected the vigor of the seedlings, contributing to its shorter length, due to the increased incidence of fungi in the seeds and thereby reduced germination rate (Figure 2).

The performance of the seedling shoots from seeds treated with clove oil increased as a function of the concentrations used, reaching a maximum of $7 \mathrm{~cm}$ at the concentration of 2 $\mathrm{mL}$ (Figure 3B). Copaiba oil contributed to the highest shoot length $(5 \mathrm{~cm})$ when the seeds were treated with the concentration of $1.25 \mathrm{~mL}$, while the treatment with fungicide did not increase seedling length when compared with those from the control, as suggested by no statistical difference in the two analyzed variables between the treatments (Figure $3 \mathrm{~A}$ and $\mathrm{B}$ ).

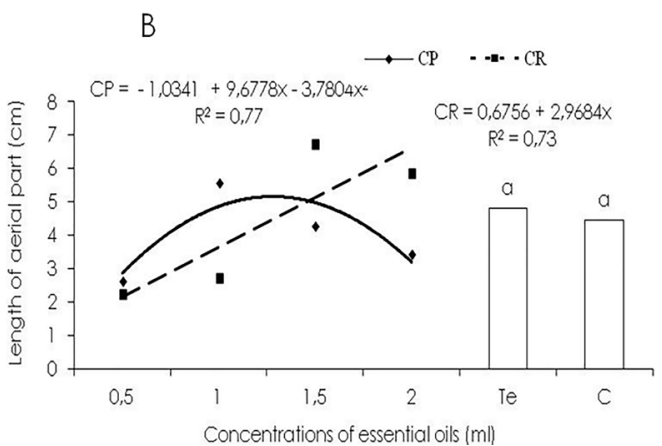

Figure 3. Length of the root (A) and aerial part (B) of Dimorphandra gardneriana seedlings after treatments with clove $(C R)$ and copaiba (CP) oils at concentrations of $0.5,1.0,1.5$, and $2.0 \mathrm{~mL}$. (Te) = control, $(\mathrm{CA})=\mathrm{Captan} \AA$ fungicide.

There was no significant difference in the dry mass of the roots and shoots between the control and the chemical treatment (Figure $4 \mathrm{~A}$ and $\mathrm{B}$ ), but an increasing linear correlation was observed between the concentrations of essential oil of clove and both variables, proving that the highest concentration did not affect the physiological quality of the seeds and promoted a higher dry mass content of roots and shoots in relation to other treatments.

The changes in the root dry mass of seedlings originating from seeds treated with copaiba oil did not fit the regression models. The mean root dry mass was $0.0774 \mathrm{~g}$ and, unlike the shoot dry mass, followed a quadratic behavior, reaching the maximum value of $0.499 \mathrm{~g}$ in treatments with $1 \mathrm{~mL}$ of the oil (Figure 4B). The seedlings of mulungu (Erythrina velutina) grown from seeds that were collected from the city of Areia and subjected to thermal and chemical treatments reached a larger dry mass (Oliveira et al., 2009).

Several studies have been carried out to identify new methods that may substitute chemical products in seed treatment, such as thermotherapy (Oliveira et al., 2009), application 

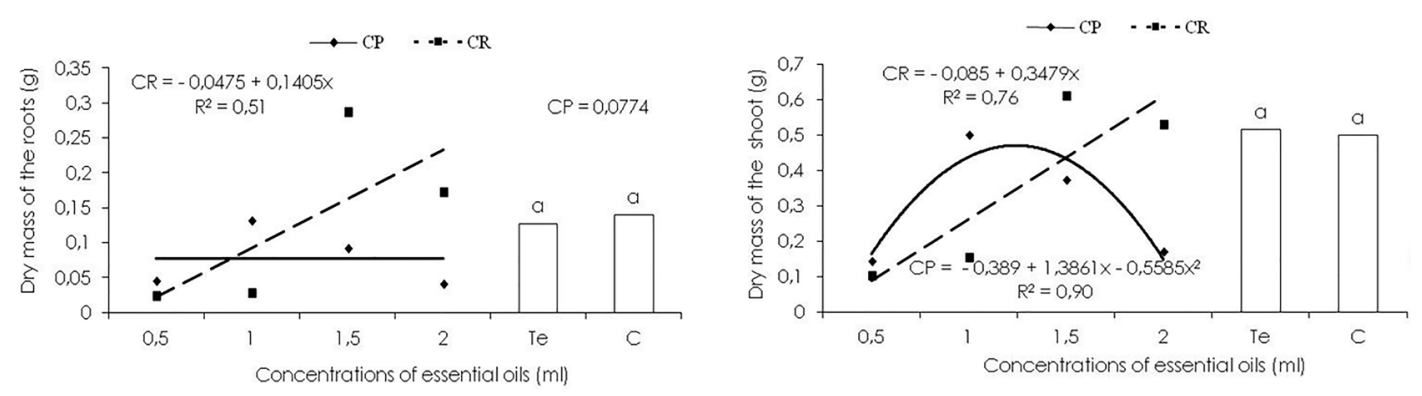

Figure 4. Dry mass of the roots (A) and shoots (B) of Dimorphandra gardneriana seedlings after treatments with clove $(\mathrm{CR})$ and copaiba $(\mathrm{CP})$ oils $(0.5,1.0,1.5$, and $2.0 \mathrm{~mL})$. (Te) = control, $(\mathrm{CA})=$ Captan $\AA$ fungicide.

of biological organisms (Marroni et al., 2012), use of plant extracts and essential oils (Leite et al., 2012; Flávio et al., 2014), and seed exposure to microwaves (Knox et al., 2013), among others.

Substitution of chemical fungicides by natural products in seed treatment may be a viable alternative, since alternative products when supplied in adequate quantities do not adversely affect seed vigor, which can lead to healthy and vigorous seedlings. In addition, they can also effectively control the incidence of many fungi, thus reducing the risk of contamination as there is an increased concern about the fate of the applied chemicals in the natural environment and their direct and indirect influences on human health (Knox et al., 2013). The results of the present study indicated that the use of natural products is a promising alternative to the use of chemicals.

\section{Conclusions}

Copaiba oil at the concentrations used does not satisfactorily reduce the incidence of fungi present on $D$. gardneriana seeds.

The concentration of $2 \mathrm{~mL}$ of clove oil reduces the incidence of the fungi Aspergillus niger and Penicillium sp., and at the concentration of $0.5 \mathrm{~mL}$ reduces the incidence of Rhizopus in the seeds of this species.

Clove oil at the concentration of $2 \mathrm{~mL}$ and copaiba oil at the concentrations of 1 to 1.5 $\mathrm{mL}$ provide satisfactory seed germination and vigor.

\section{Referências}

Brasil. Ministério da Agricultura, Pecuária e Abastecimento. 2009. Regras para análise de sementes. Secretaria de Defesa Agropecuária. MAPA/ACS, Brasília, Brasil. 395 p.
David, E.F.S. Boaro, C.S.F., Marques, M.O.M. 2006. Rendimento e composição do óleo essencial de Mentha piperita L., cultivada em solução nutritiva com diferentes níveis de fósforo. Revista Brasileira de Plantas Medicinais 8: 183-188.

Flávio, N.S.D.S., Sales, N.L.P., Aquino, C.F., Soares, E.P.S., Aquino, L.F.S., Catão, H.C.R.M. 2014. Qualidade sanitária e fisiológica de sementes de sorgo tratadas com extratos aquosos e óleos essenciais. Semina: Ciências Agrárias 35: 7-20.

Gonçalves, A.C., Reis, C.A.F.V., Vieira, F.A., Carvalho, D. 2010. Estrutura genética espacial em populações naturais de Dimorphandra mollis (Fabaceae) na região norte de Minas Gerais, Brasil. Revista Brasileira de Botanica 33: 325-332.

Knox, O.G.G., Mchugh, M.J., Fountaine, J.M., Havis, N.D. 2013. Effects of microwaves on fungal pathogens of wheat seed. Crop Protection 50: 12-16.

Landim, L.P., Costa, J.G.M. 2012. Dimorphandra gardneriana Tulasne (fava d'anta) - uma abordagem etnobotânica e riscos de extinção. Revista da Biologia 9: 6-11.

Lazarotto, M., Muniz, M.F.B., Santos, A.F. 2010. Detecção, transmissão, patogenicidade e controle químico de fungos em sementes de paineira (Ceiba speciosa). Summa Phytopathologica 36: 34-139.

Lazarotto, M., Muniz, M.F.B., Beltrame, R., Santos, A.F., J Müller, U., Araújo, M.M. 2013. Tratamentos biológico e químico em sementes de Cedrela fissilis para controle de Rhizoctonia sp. Cerne 19: 169-175.

Leite, R.P., Medeiros, J.G.F., Nascimento, L.C., Araújo Neto, A.C., Gomes, E.C.S., Malta, A.O. 2012. Qualidade fisiológica de sementes de sabiá (Mimosa caesalpiniaefolia Benth) tratadas com extratos vegetais. Scientia Plena 8: 1-5.

Marroni, I.V., Moura, A.B., Ueno, B. 2012. Chemical and biological treatments of castor bean 
seeds: effects on germination, emergence and associated microorganisms. Revista Brasileira de Sementes 34: 21-28.

Martins Netto, D.A.M., Faiad, M.G.R. 1995. Viabilidade e sanidade de sementes de espécies florestais. Revista Brasileira de Sementes 17: 75-80.

Machado, J.C. 2000. Tratamento de sementes no controle de doenças. UFLA, Lavras, Brasil. 138p.

Marthur, S.B., Kongsdal, O. 2003. Common laboratory seed health testing methods for detecting fungi. International Seed Testing Association, Basserdorf, Alemanha. 425 p.

Medeiros, J.G.F., Silva, B.B., Araújo Neto, A.C., Nascimento, L.C. 2012. Fungos associados com sementes de flamboyant-mirim (Caesalpinia pulcherrima): incidência, efeito na germinação, transmissão e controle. Pesquisa Florestal Brasileira 32: 303-308.

Mesquita, J.B., Matheus, B.N., Santana, G.C. Levantamento da micobiota associada às sementes de angico vermelho (Anadenanthera macrocarpa Benth.), copaiba (Copaifera langsdorffii Benth.) e jacarandá-da-Bahia (Dalbergia nigra Fr. All.). In: Simpósio Brasileiro de Patologia de Sementes, 7, 2002, Sete Lagoas. Anais... Embrapa Milho e Sorgo, Sete Lagoas Brasil. 2002. p.65.

Mondego, J.M., Melo, P.A.F.R., Pinto, K.M.S., Nascimento, L.C., Alves, E.U., Batista, J.L. 2014. Controle alternativo da microflora de sementes de Pseudobombax marginatum com oléo essencial de copaíba (Copaifera sp.). Bioscience Journal 30: 349-355.

Montano, H.G., Silva, G.S., Rocha, R.C., JimeneZ, N.Z.A., Pereira, R.C., Brioso, P.S.T. 2007. Phytoplasma in "fava d'anta" tree (Dimorphandra gardneriana) in Brazil. Bulletin of Insectology 60: 147-148.

Oliveira, M.D.M., Nascimento, L.C., Alves, E.U., Gonçalves, E.P., Guedes, R.S. 2009. Tratamentos térmico e químico em sementes de mulungu e efeitos sobre a qualidade sanitária e fisiológica. Revista Caatinga 22: 150-155.

Oliveira, M.D.M., Nascimento, L.C., Alves, E.U., Gonçalves, E.P., Guedes, R.S., Silva Neto, J.J. 2011. Qualidade sanitária e fisiológica de sementes de Amburana cearensis A.C. Smith submetidas à termoterapia e tratamento químico. Acta Scientiarum Agronomy 33: 45-50.

Pieri, F.A., Mussi, M.C., Moreira, M.A.S. 2009. Óleo de copaíba (Copaifera sp.): histórico, extração, aplicações industriais e propriedades medicinais. Revista Brasileira de Plantas Medicinais 11: 465472.
Pinto, N.F.J.A. 2001. Tratamento químico de grãos de sorgo úmidos visando o controle de fungos de armazenamento. Revista Brasileira de Armazenamento 26: 55-59.

Pinto, K.M.S., Barbosa, L.A., Barbosa, D.S., Nascimento, L.C., Araujo, A.K.O., Bruno, R.L.A. 2014. Sanidade e fisiologia de sementes de pimenta cambuci Capsicum baccatum L. var. pendulum tratadas com extrato de Lippiam icrophylla. Bioscience Journal 30: 743-749.

Torio, M.A.O., Saez, J., Merca, F.E. 2006. Physicochemical characterization of galactomannana from sugar palm (Arenga saccharifera Labill.) endosperm at different stages of nut maturity. Philippine Journal of science 135: 19-30.

Silva, L.G., Cosmi, F.C., Jesus Junior, W.C., Souza, A.F., Moraes, W.B. 2011. Efeito do tratamento químico na sanidade de sementes de espécies florestais. Ciência Floresta 21: 473-478. 